\title{
Poétikai modernség Arany balladáinak alkotott nyelvében*
}

1. Bevezetés. Arany János az 1850-es években megújította költészetét, annak poétikáját. Ez a megújítás összetett módon történt meg. Egyrészt Arany kidolgozott egy olyan lírapoétikát, a hozzá tartozó nyelvvel együtt, amely példa nélküli volt korábban, másrészt balladákat írt, amelyek jelentős mértékben különböznek a lírai versektől. Mindeközben erőteljesen dolgozott epikai müvein, a Toldi és a Toldi estéje nyomán (ide tartozik a Daliás idők két dolgozata, A földrengés, a Keveháza, a Csaba királyfi, az Előhang, valamint a Csaba-trilógia első dolgozata). Emellett olyan költemények is készültek, amelyek korai költészetére és a korábbi évtizedek verselésre voltak jellemzőek. Jóllehet Arany 1850-es évekbeli költészetének záró korszakhatára nem éles (a kezdete inkább), a korai modern lírai versek ekkori gazdagsága ezt az évtizedet külön is sajátossá teszik az életmüben. Talán nincs olyan szakasza Arany költői művének, amely poétikailag ennyire összetett, sokféle lenne. Az alábbiakban e korszakból a balladák poétikájának alkotott nyelvi jellemzőiről lesz szó, az 1848 előtti epikus és az 1850-es évek lírai müveinek viszonyában. Amellett érvelek, hogy az 1848 előtti epikus költészet és az 1850-es évekbeli líra már egyedi költői nyelve, poétikája mellett és azokkal szoros összefüggésben, de mégis elkülönülve Arany a korai balladákban ismét egy másik, immár harmadik költői nyelvváltozatot dolgozott ki. Ez a nyelvváltozat meghaladja az első korszak szintézisét népiesség és klasszicista retorika között, és belső választ ad az 1850es évek Arany-féle lírájának korszakváltó, sztenderd közeli nyelvváltozatára is, a kettőnek egy újabb, emergens szintézisével. A balladák nyelve egyúttal vissza is vesz a lírai versek gyökeres váltásából. A poétikai történeti folyamat nem csupán a magyar irodalom, szükebben a költészet alakulástörténetének cselekvő összetevője, hanem tágabban a magyar nyelv történetének egy igen fontos szakaszához járul hozzá. Ez a korszak a sztenderd magyar nyelvváltozat kodifikációja (első modern értelemben vett rögzítése) 1848 előtt, majd kiterjesztése a 19. század második felében. A sztenderdizáció egyszerre volt e korban a kapitalista társadalom kommunikációs igényeinek a kielégítése, a nemzetfogalom kialakításának szerves és hangsúlyos része és a művelődési, művészi modernizáció tényezője.

Az áttekintés a kognitív nyelvészet és poétika keretében történik (vö. LANGACKER 1987, 2008; KEMMER-BARLOW 2000; BRÔNE- ANDAELE eds. 2009; SEMINO-CULPEPER eds. 2002; STOCKWELl 2002; SIMON 2016; TSUR 2008; HORVÁTH-SZABÓ 2013). A kognitív nyelvészet elmélete és módszertana a közös jelentésképzést állítja a középpontba, egyrészt az emberi megismerő képességek és tevékenységek nyelvi sémáinak és azok megvalósulásaink azonosításával, másrészt a mindenkori beszédhelyzet (diskurzusvilág, kontextus) környezeti jellemzőinek

* A tanulmány az OTKA K100717 Funkcionális kognitív nyelvészeti kutatás című pályázati támogatása keretében készült. Köszönet illeti a tanulmány két lektorát, SIMON GÁBORt és TÁTRAI SZILÁRDot részletes, gondos és segítő javaslataikért.

Magyar Nyelv 113. 2017: 394-405. DOI: 10.18349/MagyarNyelv.2017.4.394 
figyelembe vételével. A poétikai összetevő itt a nyelvi megformáltságra irányított figyelem, a szövegalkotó és a befogadó egyaránt kreatív müveleteiben, úgy, ahogy az elme a megformáltságra reagál, a megismerés egy humánspecifikus módjaként.

A nyelvtörténet és az irodalomtörténet is hajlamos a nyelvet rendszerében vagy ettől elvonva egy-egy mü poétikai megvalósulásában tekinteni. Ám a nyelvet dialogikus és diszkurzív emberi tevékenységként felfogva szembetünő, hogy főképp a 19. század első harmadától egyes költők, és majd később prózaírók saját nyelvváltozatot dolgoztak ki valamely korszakukban (például Babits Mihály az első kötetének szinkretizáló nyelvi összetettségében vagy Móricz Zsigmond az Erdély-trilógiában, és megint másképp a Rózsa Sándorban). A költői nyelvváltozat ebben az értelemben egyrészt az adott nyelv stíluspotenciáljának egy meghatározott irányú kimunkálása, másrészt a potenciálnak a specifikus szociokulturális tényezőkhöz illesztése (például a beszélői viselkedés, a beszédhelyzet megkonstruálása, a nyelvtörténeti időben való elhelyezése vagy az értéktelítettség tekintetében; vö. TOLCSVAI NAGY 2012). Az ekképp kialakított beszédmód kellő koherencia és poétikusság esetén önálló költői nyelvváltozatként léphet müködésbe, jellegzetesen elkülönülve akár a költő vagy író más müveinek vagy korszakának beszédmódjától.

2. A Toldi és a lírai versek poétikája. Arany életmüvének első két nyelvalkotó periódusa a korábbi magyar költészetet messze meghaladó eredményeket hozott (1. NÉMETH G. 1971; SZEGEDY-MASZÁK1972, 1980; TOLCSVAI NAGY 2017). E jellemzőket itt röviden összefoglalva lehet fölidézni. Arany János költészetének 1848 előtt korszakát a magyar nyelv és irodalom története szempontjából a következők jellemezték: a magyar nyelv sztenderd változatának a kodifikációja; - az egyéni nyelvi alkotás és a közösségi nyelvi konvenciók viszonyának több irányú feldolgozása; - a nyelvváltozatok és a nyelvtörténeti múlt adatainak jelen idejű értékként kezelése; - irodalomtörténeti korszakok (klasszicizmus, szentimentalizmus, biedermeier, népiesség, romantika) egymásra következése vagy együttes müködése, irodalmi reflexióval; - a nyelv nemzetalkotó és esztétikai szerepének felismerése.

A sztenderd nyelvváltozat megjelenése és fokozatos bevezetése megváltoztatta a magyar nyelv és az azt beszélő nyelvközösség belső szerkezetét és értékrendjét. Bár a kodifikált nyelvváltozat egyes kérdéseiben további viták folytak (és folynak ma is), vagyis a kodifikáció nem zárult le, a sztenderd fö jellemzői müködésbe léptek. E fő jellemzők közé tartozik az általános, a teljes nyelvközösségre kiterjedő érvényesség és használhatóság, a modernizálódó, kapitalizálódó magyar társadalom és kultúra igényeinek megfelelő egyértelmüség és pontosság, a nemzeti egységet jelképező tartalom, valamint az ezekből (is) eredő tekintély.

Emellett a 19. század első felében vált nyilvánvalóvá a résztvevők számára, hogy irodalmi korszakok és irányzatok követik egymást, vagy léteznek egymással párhuzamosan (SZEGEDY-MASZÁK 1980; LAMPING Hrsg. 2011: 353-393). Az 1848 előtti magyar költészet is erőteljesen párhuzamban, autentikusan alakult, Arany kivált nagy figyelmet fordított az európai irodalom újabb irányaira, és azokra válaszolva dolgozta ki saját poétikáját és költői nyelvét, több változatban. Ezek a nyelvváltozatok a magyar költői nyelv általa létrehozott alkotásai. A költői nyelv kidolgozásában Arany vagy meglévő nyelvváltozatokra épített, abból szin- 
tetizált sajátot (mint az első korszakában), vagy lényegében újat dolgozott ki (a többi korszakában).

A Toldi mint Arany poétikája első változatának prototipikus müve szintézisre épül, melynek fontos nyelvi és ebből eredő poétikai tényezői a következők (részletesebben 1. TOLCSVAI NAGY 2017): a klasszikus és barokk, klasszicista retorika és poétika, az egyetemes költői münyelv fölényes kezelése, elsősorban az alakzatok és szóképek alkalmazásában; - a magyar népnyelv egyfajta általános kidolgozása; - a biblikus protestáns nyelvi hagyomány beillesztése a klasszikus irodalmi és népnyelvi összhangba; - a népi élőszóbeli mondatok, azaz tagmondatok természetes illesztése a verssorhoz; - a klasszikus poétikai és a magyar népnyelv példátlanul gördülékeny, simulékony összeillesztése; - a több elemből harmonizált nyelv következetes, kiegyensúlyozott poétikai alkalmazása, a mü nyelvi egységessége; - a kialakított költői nyelvváltozatokat Arany és társai egyértelmüen a nemzeti közösség önalkotó folyamataként tekintették.

Az 1850-es években írt lírai Arany-versek lényegében új poétikát és költői nyelvet vezettek be a magyar irodalomba. Itt megmutatkozik az, hogy a líra monologikus, abszolút (nincs helyzethez kötve), strukturálisan egyszerü, önmagának áll, önmagában értendő és érthető, amelyre az esztétikai komplexitás jellemző, poétikai (például metaforikus, szimbolikus) viszonyok révén, formálisan a versforma által (vö. LAMPING 1993: 63; 1. még LAMPING Hrsg. 2011: 35-105). A líra személy általi beszéd versben, a megszólalás szituáltságában, jelen időfolyamatban, a most-pontok egymásra következésében, amelyre a poétikusság, önmagára irányuló szöveg, nyelv jellemző (ez utóbbira 1. KULCSÁR-SZABÓ 2007: 13-184). E már a modernség értelmében énközpontú líra fö nyelvi jellemzői a következők (részletesebben 1. TOLCSVAI NAGY 2017): a lírai nézőpont a személyiség autopoietikus megalkotására összpontosít, alapvetően szubjektivizációs jelleggel; - a sztenderd közeli nyelvváltozat az autonóm személyiség megszólalását teszi lehetővé, a szubjektum egzisztenciális bizonytalanságával együtt; - a mondatszerkezet viszonylag egyszerü, összefüggésben a verssor rövidebbé válásával; - a szókészleti és idiomatikus elemek többségben sztenderd jellegúek; - a szemantikai összetettség növekedése, összefüggésben a metafora dinamikus szövegszintü alakításával, hatókörének rendszeres kiterjesztésével; - a népnyelvi és klasszikus retorikai elemek háttérbe szorulnak.

3. A balladák az 1850-es években. Arany költészete az 1850-es években sok poétikai irányban tájékozódott. Költői nyelvalkotását tekintve egyrészt kereste az 1848 elötti népiességen túlmutató nyelvi megoldásokat, másrészt az irodalmi nyelven (sztenderden) írt lírai versei mellett párhuzamosan más (de a többitől nem független) nyelvváltozatot dolgozott ki ekkori epikus müvei, az itt elemzendő balladái számára.

A korábbi népi és az éppen általa megalkotott sztenderd sémák átírása, újraírása, bizonyos fokú szétdúlása történik itt meg. E poétikatörténeti folyamatnak több oka is körvonalazható. Az egyik föltehetőleg a (szociolingvisztikai értelemben vett) sztenderd nyelvváltozatú lírai verseknek a nemzeti költészeti programhoz való viszonya: Arany ezt a később oly hatásos, de a nemzeti jellegtől (főképp lát- 
szólag) távolodó eredményét talán ellensúlyozni kívánta a népi gyökerü müfajjal. Az ellensúlyozás igénye aligha véletlen: Arany éppen az 1850-es években dolgozott legerőteljesebben a magyar népi eposz „újjáírásán” vagy megírásán, és az epikai, történeti irányultságát erősítette saját életében a kritikai befogadás is. Másrészt a Toldi kivételes szintézisében megvalósított bennfoglalt és nyílt népi képviseleti nézőpontot abban a formában már nem lehetett folytatni, ezért Arany új megoldásokat keresett. Olyan poétikai és nyelvi megoldásokat, amelyek lehetővé teszik a nemzeti költői paradigma folytatását, de immár tagoltan, összetettebben.

Az epikusnak és a lírainak, az objektívnak és a szubjektívnak, az eszménynek és a valóságnak ekkor már nem a korábbi közvetlen, a feszültségeket feloldó harmonizálása, hanem e kettősségek különböző változatú kidolgozása, nyílttá tétele az 1850-es évek balladáinak az egyik fö poétikai jellemzője.

A kortárs irodalmi világ Arany balladáit, epikai költői teljesítményét ünnepelte. A befogadástörténet e jellegének egyik fő oka az irodalmi népiességnek, a nemzeti irodalmi programnak a folytatása és a kortársak számára is látható megújítása volt (vö. NÉMETH G. 1971; IMRE 1996: 49-70). A poétikai vonatkozások mellett lényeges volt a balladák dramatizáltsága, amely párhuzamban állt az önkényuralom közvetlen tapasztalatával. A nemzeti sorsra utaló elemeket erősítették a magyar, nemzeti történelmi témák és utalások.

Emellett a drámai helyzet, a gyakran tragikus történet a kivételesen pontos, feszes és tömör, az elbeszélő és párbeszédes részeket, sőt a beszélői nézőpontokat is váltogató versszerkesztéssel együtt valóban a magyar költészet leghatásosabb művei közé helyezi a balladákat, még ha azok nem is egyforma minőségüek.

Az Arany-balladák különlegességét a müfaj kortárs sajátossága is erösíthette megjelenésükkor. A ballada részben idejétmúlt, nem autentikus múfajnak bizonyult az európai költészetben, ugyanakkor az Arany-féle megújítás éppen az átértelmezett korszerüséget mutatta fel (IMRE 1996: 49-70, 97-135). A korszak, az 1850-es évtized messze ható meghatározó műve Baudelaire nevezetes verseskötete volt, amely erős kontrasztban állt Arany nemzeti epikai kísérleteivel, míg az Arany-féle líra éppen azzal mutatott rokonságot.

4. Poétikai jellemzők a balladákban. Ahogy a korábbi dolgozatomban, úgy ebben is a nyelvváltozatok, a perspektiválás, a szubjektivizáció és objektivizáció szempontjából elemzek balladarészleteket az alábbiakban.

A perspektiválás az a mód, ahogyan, amilyen nézőpontból Arany megszólaltatja versbeli beszélőjét. A perspektiválás egyik legfőbb módja Arany esetében a történetileg kialakult nyelvváltozatok költői, poétikai alkalmazása, módosításokkal, illetve új nyelvváltozatok kidolgozása, amint azt a lentebbi részek bemutatják. A perspektiválás nyelvi mủveletei közül kiemelendő az objektivizáció és szubjektivizáció kettőssége, valamint az episztemikus lehorgonyzás. A beszélő mint szubjektum és a mondat által kifejezett jelenet résztvevője mint szubjektum megkonstruálása, azaz mondat- és szövegbeli nyelvi kifejezése közötti különbség a szubjektivizáció és az objektivizáció jellemzőiben mutatkozik meg (LANGACKER 1987: 141-146). 
Egyes esetekben egy mondatban a résztvevőket a beszélő nyíltan kifejezve, objektívan konstruálja meg, vagyis a résztvevők a beszédhelyzettől elválasztva jelennek meg (még ha a beszélő és a hallgató is résztvevő a mondatban). Vagyis a beszélő a mondat vagy szövegrészlet létrehozójaként saját beszédhelyzetével együtt nem része a mondatnak vagy szövegrészletnek.

Más esetekben a beszélő bennfoglaltan a konceptualizáció részévé válik. A szubjektivizáció során a beszélő nézőpontja bennfoglaltan érvényesül, közelebbről az a tény és mód, ahogyan a beszélő a hallgató figyelmét irányítja saját témájával kapcsolatban. A beszélö saját nézőpontját jelzi: innen és innen konstruálja meg a jelenetet, ez és ez a véleménye, hiedelme, magatartása az adott témával kapcsolatban. Továbbá azt is érzékelteti bennfoglaltan, hogy a vélekedés, a perspektiválás kitől származik. „Egy entitás objektívan konstruálódik addig a mértékig, ahogy »színen « van mint a konceptualizáció explicit, fókuszált tárgya. Egy entitás szubjektívan konstruálódik addig a mértékig, ahogy »színen« kívül marad mint a konceptualizáció implicit, nem öntudatos alanya. A szubjektivizáció a rejtett konceptualizáló jelenlét jelölése, amelyre az önmagára irányuló figyelem (önreferencia, önazonosítás) teljes hiánya jellemző, miközben a kifejtett jelenet mint a konceptualizálás célja feltünő, jól körülhatárolódik, megértése kellő pontossággal történhet, vagyis objektivizált" (LANGACKER 2006: 18). Aszimmetria van a szubjektivizált és objektivizált elemek között. Egy kifejezés jelentése mindig tartalmaz szubjektívan és objektívan konstruált elemeket. A szubjektívan konstruált elemek közé tartozik elsősorban a beszélö és másodlagosan a hallgató, a mondatbeli jeleneten kívüli konceptualizáló szerepükben.

Az V. Lászlóban például szubjektivizáltan mutatkozik meg a versbeli elbeszélő nézőpontja, együttérzése a Hunyadi családdal és pártolóikkal:

Mélyen a vár alatt

Vonúl egy kis csapat;

Illetve:

„A nép, uram király,

Csendes, mint a halál,

Csupán a menny dörög."

Az első idézetben a kis jelző a menekülők kiszolgáltatottságát, sebezhetöségét jelöli együttérzően. A második részletben a menny dörgése (kiemelve) egyszerre utal a baljós természeti körülményre (a viharra) és Isten ítéletére, ismét a beszélö határozott értékszempontja felől.

A nyelvi közlések episztemikusan le vannak horgonyozva: a dolgokat és a folyamatokat a beszélőtársak egyedítik a nyelvi szerkezetekben. Az episztemikus lehorgonyzásban a dolgok és a folyamatok lehetséges csoportjából, vagyis típusából azonosíthatóvá válik az a példány, illetve azonosíthatóvá válnak azok a példányok, amelyeket a beszélö a beszélőtársak figyelmének középpontjába kíván 
állítani (LANGACKER 1987: 126-129; BRISARD 2002). A lehorgonyzás a beszélőtársak figyelemirányításán, pillanatnyi tudástartományán belül történik meg, a mindenkori beszélő és hallgató által feldolgozott saját fizikai, szociális és mentális helyzetükkel (alapbeállításban én, te, itt, most) viszonyban.

Arany balladáiban az objektivált és szubjektivált elemek változatossága többek között a beszélöi kiindulópontok váltogatásából, az alakzatok és a metaforizálás egyedi megvalósulásaiból ered.

A Szondi két apródja szövegében a verssorok és a mondatok viszonylagos rövidségük ellenére is teljesek grammatikailag és retorikailag is. E jelleg a mondatok kifejtőbb jellegéből ered: mind a történetelbeszélés, mind az idézetek minden lényeges elemet (szereplőt, folyamatot, körülményt) megneveznek. A mondatok elemi jelenetleképezését egy-egy jelző teszi fogalmilag és poétikailag érdekesebbé, kiemelve a megnevezett tulajdonság fontosságát.

Felhöbe hanyatlott a drégeli rom,

Rá visszasüt a nap, ádáz tusa napja;

Szemközt vele nyájas, szép zöld hegy-orom,

Tetején lobogós hadi kopja.

$[\ldots]$

Mondjad neki, Márton, im ezt felelem:

Kegyelmet uradtól nem vár soha Szondi,

Jézusa kezében kész a kegyelem:

Egyenest oda fog folyamodni.

E balladában a transzmutációs szerkezetek poétikai szerepe nagy, bár nem uralja úgy a vers szövegét, mint például A walesi bárdokban. Az enyhén szokatlan szórendi változatok részben a megnevezett események mozgalmasságát és tragikumát, részben a megformálás artisztikumát fejezik ki:

A vár piacára ezüstöt, aranyt,

Sok nagybecsü marhát máglyába kihordat;

Harcos paripái nyihognak alant:

Szügyeikben tört keze forgat.

A ballada többszörös beszélői perspektívát egyesít: beszélő és a török váltja egymást, bár a harmadik versszak idézetét Ali, a hadvezér mondhatja, de megszólal az Alinak válaszoló személy, és maguk az apródok is, megidézve Szondi nézőpontját is. A narráció és az egyenes idézetek alapvetően objektivizált konceptualizációk. Az elbeszélő szövegét azonban kifinomult szubjektivizációs jelzések teszik összetettebbé, jelentős mértékben megmutatkozik a beszélői perspektíva és a kidolgozott poétikusság. Ezek olyan szubjektivizált kifejezések, amelyek a versbeli megszólaló hovatartozását, együttérzését mutatják meg. Például a második versszakban a két apródról enyhén archaizálva és emelkedetten beszél, míg a török parancsnokot egyszerü nevén említi, hadseregét pedig a rendezetlen zajongással jellemzi: 
Két ifiu térdel, kezökben a lant, A kopja tövén, mintha volna feszület. Zsibongva hadával a völgyben alant

Ali győzelem-ünnepet ület.

A ballada egyes pontjain az elbeszélő bennfoglalt, szubjektivizált nézőpontja határozottan előtérbe kerül. Például a „Hogy vítt ezerekkel!” kezdetü versszak csodálatot megjelenítő felkiáltásai ezt az értékelő, együttérző nézőpontot képezik le. A vers utolsó versszaka, az átok vagy átokkérés pedig nyílttá teszi a saját magát színre nem vivő beszélő nézőpontját.

$\mathrm{Az} \mathrm{V}$. László a rövid mondatok és verssorok révén alapozza meg a drámai feszültséget. E balladára a nagymértékü bennfoglalás jellemző az elbeszélő részekben:

Sürü setét az éj,

Dühöng a déli szél,

Jó Budavár magas

Tornyán az érckakas

$[\ldots]$

Csikorog élesen.

Megcsörren a bilincs,

Lehull, gazdája nincs:

Buda falán a rab

- Egy-egy felhődarab -

Ereszkedik alá.

A két kiemelt versszakban a baljóslatú helyzetet nem a történet valamely epizódjának a részletes elbeszélése adja meg elbeszélői megjegyzésekkel, hanem egyrészt metonimikus természeti utalások (dühöngő vihar, bilincs, a kakas éjszakai, hajnali megszólalása), másrészt metaforikusak ( $\mathrm{rab}$ - felhő). Ez a figurativitás sztereotip, nem különösebben eredeti, a vers szövegében azonban egyedivé és összetetten jelentésessé válik.

A vers más helyén a párhuzam és az ellentét szubjektivizált bennfoglalásai növelik a feszültséget a szemben álló felek között úgy, hogy mind V. László, mind a szökésben lévő Mátyás és hívei félelmeit jelzi a szöveg, ismét a természeti körülmények kifejezéseinek metonimikus kiterjesztéseivel:

Az alvó aluszik,

A bujdosó buvik;

Ha zörren egy levél,

Poroszlót jőni vél

[...]

Kanizsa, Rozgonyi.

Az alvó felvirad,

A bujdosó riad; 
Szellő sincsen, de zúg,

Felhő sincsen, de búg

$\mathrm{S}$ villámlik messziröl.

A népiesség a nyelvi megformálásban alig mutatható ki ebben a versben. Az V. László szövege sztenderd (irodalmi nyelvi) alapokra épül, amelyben a metaforizálás és az alakzatosság kiinduló szerkezetei nem népi tapasztalatból erednek, inkább a magyar egyetemes kultúra konceptualizációiból. Mindez érvényes az idézett élőszóbeli részletekre, párbeszédekre is. Tömörségük, rövidségük és bennfoglaló (lényeges elemeket megnevezetlenül hagyó) karakterük nem a hagyományos népi, paraszti beszéd kizárólagos tulajdonsága.

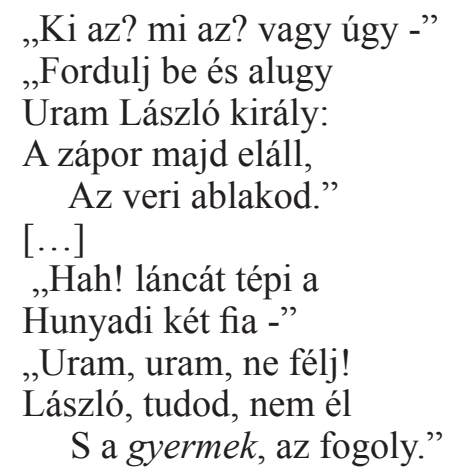

A bennfoglalások egyértelmủen megmutatják, hogy a szövegben önmagát közvetlenül meg nem jelenítő elbeszélő hogyan foglal állást a drámai konfliktusban. Így kap formát V. László rövid kérdéseiben a bennfoglalt erkölcsi feszültség, a büntudat:

„Miért zúg a tömeg?

Kivánja eskümet?"

„A nép, uram király,

Csendes, mint a halál,

Csupán a menny dörög."

Ebből a bennfoglaló beszédmódból lép ki az elbeszélő az utolsó versszakban, a már implikálva fölépített morálra helyezve a végső erkölcsi parancsot.

A walesi bárdok rendkívüli összetettségü poétikai jellemzőiből itt csak röviden lehet megemlíteni az ismét rövid verssort és a vele harmonizáló mondatszerkesztést. A balladában nyíltan megmutatkozik a tagmondat (clause, elemi mondat) legfóbb tulajdonsága: a tagmondat, elemi mondat egy jelenetet képez le szemantikai és párhuzamos szintaktikai szerkezetben, amely jelenetben a szereplők egymáshoz való időbeli viszonya a középponti rész. Arany e mondatkonstrukció-típust lehetőségei végső határáig viszi a minimalizálásban (miképp több más 
balladájában is). E mondatkonstruálás nem népnyelvi (nem paraszti nyelvi vagy nyelvjárásias), sokkal inkább általában sztenderd közeli beszélt nyelvi magyar beszédmód, poétikailag fölerösítve.

Edward király, angol király

Léptet fakó lován:

Hadd látom, úgymond, mennyit ér

A velszi tartomány.

Van-e ott folyó és földje jó?

Legelőin fü kövér?

Használt-e a megöntözés:

A pártos honfivér?

A bennfoglalások, utalások, célzások rendszere enyhe, de sürü metaforizálással, archaizálással és választékossággal kapcsolódik össze. Mindebből az alakzatok emelkednek ki. A vers talán legismertebb szakasza a magyar költészet egyik legkülönlegesebb mondatszerkezetével vált ki megismételhetetlen hatást:

Ötszáz, bizony, dalolva ment

Lángsírba velszi bárd:

De egy se birta mondani

Hogy: éljen Eduárd. -

Az idézett szakasz első két sora egy mondat, egyedi transzmutációs alakzat, amely a mondatbeli nyelvi elemek sorrendjéből adódik. A magyar mondat nem szabad szórendủ, ellenben a magyar mondat szórendje mutat néhány fontos jellegzetességet: a szórendi helyzet nem jelöl ki feltétlenül valamilyen mondatrészi szerepet (mint az angolban a főnévi szókezdő helyzet az alanyét), a szórend a teljes mondat ismeretében annak jelentéséhez járul hozzá.

A nevezetes mondatban az elemek a lehető legszokatlanabb módon követik egymást, olyan sorrendben, amely sorrend lényegében lehetetlen kiegyensúlyozott monologikus írott szövegben. Ugyanakkor mutat bizonyos rokonságot a spontán zaklatott beszéddel, amelyben a hirtelen feltoluló gondolatok, azaz szaggatottan, kiterjedés nélkül aktiválódó fogalmak rendje ikonikusan képeződik le. E magyarázathoz további összetevőket füzhetünk, a korábban elkülönített mondattani tényezők révén: igen nehéz megtalálni az egyes mondatösszetevők funkcióit, mert jellegzetes vonzatuktól vagy módosítójuktól többször elválasztódnak (ötszáz ... bárd), vagy sorrendjük megcserélődik (ment lángsírba); - az első tényezőből olyan mértékủ széttagolódás jön létre, amely mintegy önállósítja fogalmilag az egyes összetevőket, tehát megfelelö teret ad a teljesebb jelentésszerkezetük aktiválására; - a széttagolódást erősíti a verselés, amely egyes helyeken összetartozó konstrukciótagokat választ szét, erős ellentétben a Toldi népiességével; - az egyes összetevők mindegyike több-kevesebb mértékben megnyit egy-egy semleges kiindulópontot, legalábbis lokális érvénnyel, amíg a következő kvázi önálló összetevő be nem lép a mủveleti feldolgozás egymásra következésébe. 
Ez a konstruálási mód túllép a népi nyelvváltozatokon, azok poétizált megvalósulásain éppúgy, mint a korban éppen kodifikált sztenderd szociolektuson. Arany itt a költői beszéd határait helyezi el újra, tágabban a magyar nyelv teljességében. Nagymértékben szubjektivizált beszédmódja egyúttal határozott beszélöi jelzés a bemutatott esemény értékvonatkozásairól: a beszélő kívülről nézi a jelenetet, de beszédének nyelvi megformáltságával kifejezi együttérzését, egyetértését, a klasszikusan tragikus sorsvállalás fölött megrendülését.

5. Összefoglalás. Arany Jánosnak az 1850-es években írt balladái az Aranyéletmúben újabb alkotott nyelvváltozatot vezetnek be. Ez a nyelvváltozat elkülönül a Toldi szintetizált népiességétől, de különbözik az 1849 utáni lírai versek sztenderd nyelvezetétől is. Egyrészt epikus, elbeszélő vonásokat mutat, inkább a sztenderd nyelvváltozat keretében, másrészt rokon a lírai versekkel, de másképp, hiszen itt a közvetlen énközpontúságnak nincs nyoma, a beszélő szubjektivizáltan bennfoglalásokkal, poétikai müveletekkel jelenik meg. A korai Arany-balladák objektivizálóan epikus, de líraian szubjektivizáló alkotások a beszélő rejtett nézőpontja által. A balladákban Arany ezáltal kilép a Toldiban és a későbbi eposzi munkáiban egyértelmüen megkonstruált népi képviseleti költői alapállásból (ezt erősíti az itt nem tárgyalt irónia több helyen), ugyanakkor részlegesen megtartva újraértelmezi azt a ballada népi müfaji hagyományainak az idealizálásával. E poétikai sajátságoknak a kifejezője:

a) a sztenderd alapú nyelvváltozat, kevés, de változó mértékủ népiességgel;

b) a drámai tömörség;

c) a szemantikai telítettség;

d) az egyszerü, rövid mondatok, szorosan összekapcsolva a versritmussal és a sorhosszal;

e) visszafogott metaforizálás;

f) erőteljes alakzathasználat, nem klasszicista díszként, hanem az elbeszélö természetes, de artisztikus beszédmódjából eredően;

g) a beszélő nézőpontjának jelentősége: együttérzés és hárítás az ellentétes szereplők megítélésének megfelelően.

Kulcsszók: ballada, népnyelv, objektivizáció, poétika, sztenderd, szubjektivizáció.

\section{Hivatkozott irodalom}

BRISARD, FRANK 2002. Introduction: The epistemic basis of deixis and reference. In: BRISARD, FRANK ed., Grounding. The Epistemic Footing of Deixis and Reference. Walter de Gruyter, Berlin - New York. xi-xxxiv. https://doi.org/10.1515/9783110899801.xi

Brône, Geert - Vandaele, Jeroen eds. 2009. Cognitive Poetics. Goals, Gains and Gaps. Walter de Gruyter, Berlin - New York.

HorvÁTH MÁRTA - SZABÓ ERZSÉBET 2013. Kognitív irodalomtudomány. Helikon Irodalomtudományi Szemle 59: 139-149. 
IMRE LÁSZLÓ 1996. Müfajok létformája XIX. századi epikánkban. Kossuth Egyetemi Kiadó, Debrecen.

Kemmer, SuzANne - BARlow, Michael 2000. Introduction: A usage-based conception of language. In: BARLOW, MiCHAEL - KEMMER, SUZANNE eds., Usage-Based Models of Language. CSLI Publications, Stanford, California. vii-xxviii.

KulCSÁR-SZABÓ ZOLTÁN 2007. Metapoétika. Önprezentáció és nyelvszemlélet a modern költészetben. Kalligram, Budapest.

LAMPING, DiETER 1993. Das lyrische Gedicht. Definitionen zu Theorie und Geschichte der Gattung. Vandenhoeck \& Ruprecht, Göttingen.

LAMPING, DiETER Hrsg. 2011. Handbuch Lyrik. Theorie, Analyse, Geschichte. Verlag J. B. Metzler, Stuttgart-Weimar. https://doi.org/10.1515/infodaf-2013-2-362

LANGACKER, RonAlD W. 1987. Foundations of Cognitive Grammar. Volume I. Theoretical Prerequisites. Stanford University Press, Stanford (CA).

LANGACKER, RONALD W. 2006. Subjectification, grammaticalization, and conceptual archetypes. In: ATHANASIADOU, ANGELIKI - CANAKIS, COSTAS - CORNILliE, BerT eds., Subjectification. Various paths to subjectivity. Walter de Gruyter, Berlin - New York. 17-40.

LAngacker, Ronald W. 2008. Cognitive Grammar. A Basic Introduction. Oxford University Press, Oxford. https://doi.org/10.1075/lal.1

NÉMeth G. BÉLA 1971. Türelmetlen és késlekedő félszázad. Szépirodalmi Könyvkiadó, Budapest.

Semino, Elena - Culpeper, Jonathan eds. 2002. Cognitive Stylistics. Language and cognition in text analysis. John Benjamins, Amsterdam-Philadelphia.

SIMON GÁBOR 2016. Bevezetés a kognitív lírapoétikába. A költészet mint megismerés vizsgálatának lehetöségei. Tinta Kiadó, Budapest.

StockWell, Peter 2002. Cognitive poetics. An introduction. Routledge, London - New York.

SzEGEDY-MASZÁK MiHÁLY 1972. Az átlényegített dal. In: NÉMETH G. BÉLA szerk., Az el nem ért bizonyosság. Akadémiai Kiadó, Budapest. 291-358.

SzEGEDY-MASZÁK MiHÁly 1980. A magyar költészet föbb típusai a kései XVIII. és a korai XIX. században. In: SzEGEDY-MASZÁK MIHÁLY, Világkép és stílus. Történetipoétikai tanulmányok. Magvető Könyvkiadó, Budapest. 37-74.

TOLCSVAI NAGY GÁBOR 2012. A stílus szociokulturális tényezőinek kognitív nyelvészeti megalapozása. In: TÁTRAI SzILÁRD - TOLCSVAI NAGY GÁBOR szerk., A stílus szociokulturális tényezői. Kognitív stilisztikai tanulmányok. ELTE, Budapest. 19-49.

TOLCSVAI NAGY GÁBOR 2017. A magyar nyelv lírai újraalkotása Arany János életművében. Magyar Nyelvör 141: 143-163.

Tsur, REUVEn 2008. Toward a Theory of Cognitive Poetics. Sussex Academic Press, Brighton.

\section{Poetic modernity in the construed language of János Arany’s ballads}

The second period of the oeuvre of János Arany (1817-1882), during the 1850s, is characterized by two poetic lines. On the one hand, he developed a lyrical poetry focusing on an autonomous, individual language variety, fitting into European lyrical modernity. On the other hand, Arany re- 
interpreted, re-formed the traditional Hungarian folk ballad, with references to its wider environment and European poetry.

This latter kind of poetics elaborated by Arany is analysed in the paper through three ballads. The main features of these epic poems are as follows: (a) objectified storytelling, highly subjectified evaluation, sympathy with or refusal of the participant in the course of the tragic event, viewed from an emphatic vantage point, implicitly, and no sign of self-reference to the speaker, (b) standard register as the linguistic baseline with minor traits of rural dialects, (c) dramatic density, (d) semantic conciseness, (e) simple, short clauses, harmonized with the verse lines and rhythm, (f) moderate metaforization, and $(\mathrm{g})$ high proportion of complex figures as a natural component of the discourse.

Keywords: ballad, rural dialect, objectification, poetics, standard, subjectification.

TOLCSVAi NAGY GÁBOR Eötvös Loránd Tudományegyetem Konstantin Filozófus Egyetem, Nyitra 